\title{
Transformational Leadership and Affective Commitment at Family Businesses
}

\section{Tazhan Mahdi and Cemil Top}

To Link this Article: http://dx.doi.org/10.6007/IJARBSS/v11-i4/9797

DOI:10.6007/IJARBSS/v11-i4/9797

Received: 07 February 2021, Revised: 10 March 2021, Accepted: 29 March 2021

Published Online: 26 April 2021

In-Text Citation: (Mahdi \& Top, 2021)

To Cite this Article: Mahdi, T., \& Top, C. (2021). Transformational Leadership and Affective Commitment at Family Businesses. International Journal of Academic Research in Business and Social Sciences, 11(4), 11841195.

\section{Copyright: (C) 2021 The Author(s)}

Published by Human Resource Management Academic Research Society (www.hrmars.com)

This article is published under the Creative Commons Attribution (CC BY 4.0) license. Anyone may reproduce, distribute, translate and create derivative works of this article (for both commercial and non-commercial purposes), subject to full attribution to the original publication and authors. The full terms of this license may be seen at: http://creativecommons.org/licences/by/4.0/legalcode

\section{Vol. 11, No. 4, 2021, Pg. 1184 - 1195}

Full Terms \& Conditions of access and use can be found at http://hrmars.com/index.php/pages/detail/publication-ethics 


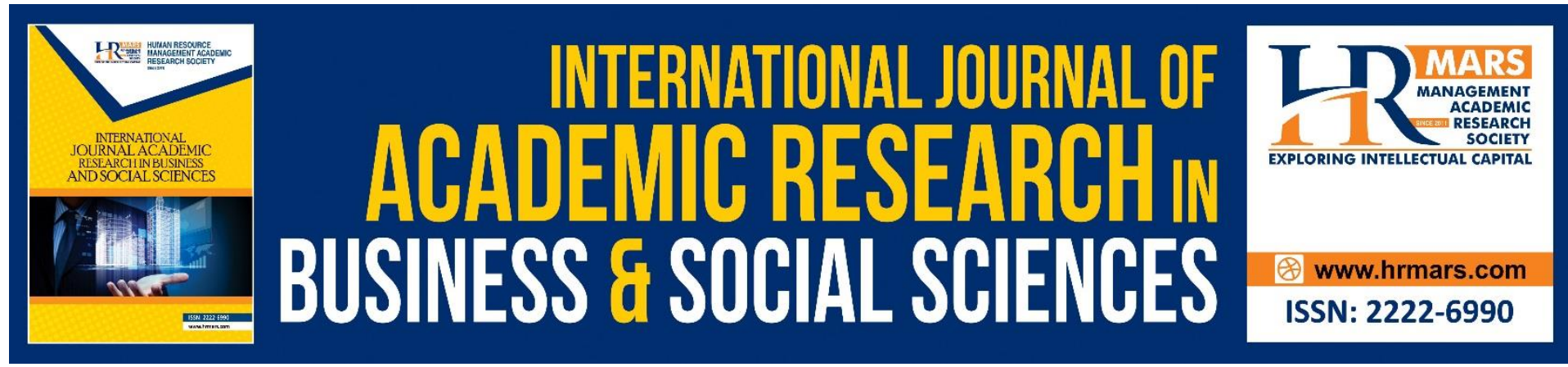

\title{
Transformational Leadership and Affective Commitment at Family Businesses
}

\author{
Tazhan Mahdi and Cemil Top \\ Tishk International University, Business and Management Department Sulaymaniyah \\ Email: tazhan.mahdi@std.tiu.edu.iq, cemil.top@tiu.edu.iq
}

\begin{abstract}
Leadership and being family member in the organization should have significant positive impact on performance and commitment. In this respect, current study initially aims to study the effect of transformational leadership on affective commitment, and secondly investigates the effect of family membership on their affective commitment in Kurdistan Region of Iraq. To do this, we have collected 345 questionnaires. Results have been evaluated through SPSS software. It has been observed that transformational leadership has positive significant impact on affective commitment, while family membership in the company has negative impact on their affective commitment. Lastly, some recommendations have been demonstrated to the family businesses.
\end{abstract}

Keywords: Transformational Leadership, Affective Commitment, Family Business, Kurdistan, Iraq

\section{Introduction}

One of the main factors of having a successful business is to create a great leadership impact in the organizations. By mentioning the word leadership, people might think of a military leader at the first time. However, leadership refers to the way of managing processes in a way that every step has been studied carefully and in detailed (Budur, 2018a). The word leadership is becoming popular day by day in Kurdish business community. People in the organizations realized that leadership is one of the key factors to build a great business (Rashid et al., 2020). As a result, organizations try to implement the concepts of leadership in their daily work. The most common leaders in the organization are the people in top positions, such as the managers, directors, and chairmen (Top et al., 2020). However, not only the top positions care about being influential leaders, the employees sometimes try to show the best examples of being a good leader to manage their work properly (Mohammed and Sahin, 2020; Serin, 2018).

The concept of leadership has many approaches and parts. Transformational leadership is one of the crucial approaches of leadership that most of the organizations and companies aim to implement. Transformational leadership can be defined as the progress that it is all parts are about the behavior and attitude, and its goal is related to achieve inspiration and motivation (Burns, 1978). All the steps of transformational leadership will be obtained successfully, when the leader provides all the needs and wants of its employees and makes them be satisfied 
with their jobs (Budur and Poturak, 2021). When the employees are satisfied and happy with their jobs and tasks, the level of productivity and efficiency increase in the organizations (Poturak et al., 2020). And that will shape the organization to achieve the long- and shortterm goals, and its effect appears more, with training which is a trusted factor by the leaders and the employees can be supported to be creative in the organization (Budur and Demir, 2019a). Also, the employees can take the place of being a leader to undertake the responsibilities of solving their own problems and issues. As a result, all the employees that work for the organization can affect the growth of productivity level of the work (White, 2018).

A transformational leader is the one that cooperates to enhance the value of the structure inside the organizations. Reward technic is one of the main effective factors to increase the productivity (Zardasht et al., 2020). The reward technic is simply the use of the rule called reward and obligation. This rule is implemented in a way that providing them the rewards that they are satisfied with, who do their work properly without mistakes (Faeq, 2020). On the other hand, the obligation is the way of punishing or making corrections for further improvements. Furthermore, transformational leaders use their positive conducts as individual care with their subordinates or stimulate follower's participation to business related activities (Budur and Demir, 2019b).

Further, employee commitment is the perception of the employee in the organization, how much they believe in the organization's value, mission, and vision (Dinc, 2017). Besides, that, the employees can be measured how much they trust in the organization and in their leader fur further favorable outcomes at their workplaces. This process can be used as a measurement to realize how many employees are satisfied and motivated with the organization. The number of the employees shows that the employees trust, believe, and are comfortable with the organization. We mean by being comfortable by how much the reward is deserved for an employee to achieved and work hard for it, how much the obligation and punishment are flexible for employee and how much hard to avoid the mistake which makes the employee stress. Also, how much the inspiration and motivation are achieving and gaining the need of employees and make them be motivated in organization (Allen and Meyer ,1990). The transformational leadership can be classified in the term to be related to behavior, attitude, motivation, and inspiration. These terms support the organizational environment that prepares the employees to deal with the customers and shareholders easily (Budur and Poturak, 2021b). Transformation leadership can create a positive impact on the employee's commitment in different ways in terms of inspiration of the employee band by providing her/his need in the organization (Allen and Meyer, 1990). By applying transformation leadership approach, the employees will be related to the organization emotionally (Budur and Demir, 2019b). So, the employees do not care very much about the salaries, even when their salaries are not the amount that they with for (Conger and Kanungo, 1994). Employees that are happy and comfortable with their organizations, more tend to provide help and support to their organizations in the hard times (Bass, 1999).

As it was mentioned above, transformation leader work on the emotion of the environment, they inspire and motivate the employee and others who in the environment. If the environment is pushed and motivated, it directly makes the way open up for success, but we shouldn't decide just by the advantages of it we should mention the disadvantages of the transformation leadership also (Budur, 2020). An example for disadvantage of transformation leader could be the burnout among the employees. By burning out we mean that the employees have too many tasks or responsibilities to fulfill, in a result they will get tired and 
stresses (Mohammed et al., 2020). Another disadvantage might be transformational leaders make ethical and flexible environment, but that environment has a cost when the leader should continue communicate and take feedback to keep the environment stable (Poturak et al., 2020).

Moreover, being successful leader requires many crucial steps. The first step is to use the right model because the follower sees it as their role model in the organization. The second point is the transformation leader must be pensioned and know how to express their passion even if he/she does not have it. The third point is that the leader must increase the communication skills. The last point is that the leader must focus on every individual and employee in the organization. By these four strategies, the organization can reach a success point with the transformation leader style (Ali and Sagsan, 2020; Burns, 1978; Tajeddini, 2015).

Consequently, the employee commitment can be counted as a fundamental factor that impacts the success of the organization because of many reasons. Employees are the main source of the organizations that create huge roles in it and without the employee and human resources the organization cannot exist at all (Ali, 2018; Demir and Budur, 2019). The employee can influence the success and failure of the organization depending on how much they committed and comfortable with the organization (Demir et al., 2020). From the basic salary till they behave and rules which they communicate with the leaders. The employee should get the opportunity to improve their skills and knowledge, and also the leader must focus on their employee's needs and desires if the employee became committed each of them became like a member of a big family and they try their best to make the organization successful (Durmaz, 2017; Demir et al., 2021).

Based on these discussions, current paper aimed to investigate the relationship between transformational leadership and employee commitment in the Kurdistan Region of Iraq. Kurdistan is culture that consist of close family connections. Hence there are many family businesses in the country. In this respect, we couldn't find any paper in line with our scope that evaluated family members contribution to their organization. Due to our observation's family businesses hire especially their family members in the key positions but the members are not so eager to keep their positions there. So that, some factors should be influential on their perceptions to keep their commitment in the workplaces. Accordingly, our study proposed the investigate the commitment of family members in their organizations based on transformational leadership behaviors.

\section{Literature Review}

Leadership is characterized as the handle in which a person impacts the bunch of people to achieve a common goal (Torlak et al., 2021). The objective is achieved by shared participation and cohesive behavior. A leader implants a sense of inspiration and coordinates others to reach the desired goal (Ulrich et al., 2017).

Further, there's a clear distinction between being a transformational leader. A good transformational leader impacts the other people in a positive way and helps them to achieve their goals (Ulrich et al., 2017). Also, he/she motivates and inspires the others to increase their productivity at work. On the other hand, a boss does not motivate its employees, he/she commands and orders them to do what she/he thinks of. Also, A boss blames the others when they make mistakes instead of making them learn from their mistakes (Hamid and Durmaz, 2021). A good leader controls the others in a way that make them perform better in their jobs, but a boss controls the other by making them be afraid from him/her. Rather on the off 
chance that one tries to control the circumstances with control, it turns out to be authoritarian or indeed suppressive in its expression. (Top et al., 2020).

Furthermore, Transformational leadership is one of the effective leadership styles in our time. They have significant impact on employee positive outcomes and organizational success. Accordingly, they have four main characteristics to attract followers. These are idealized influence, inspirational motivation, intellectual stimulation, and individual consideration (Bass, 1999, Budur and Poturak, 2021). These characters could be explained as followed,

\section{Characteristic of Transformational Leadership}

Idealized influence: A person who is identified as a transformational leader should contain some specific characteristics and behaviors. A leader's main aim in transformation leadership is the inspiration. And through these four points the leader will not just lead the employees, but also gain their trust and make them follow him/her. A transformational leader should be someone who can undertake the responsibilities of the company and should have a charismatic personality to be able to influence others. In this case, the leader can manage the tasks and projects, and will be able to distribute the duties of the employees and convince them to perform them. Also, the leader can manage that the work is done properly and efficiently (Ali and Yildiz, 2020).

\section{Inspirational Motivation}

The main goal of motivation is to involve everyone to be a part of achievement to achieve the common goal for the organization. Motivation and inspiration affect the employees and make them perform their best compensation to the company. The leader should be open and honest about the challenges and hard times of the organization (Top et al., 2020). The leader should know and understand the different situation, which he or she faced with the different characters of their followers because the main aim of transformation leader is creating opportunities for the employees not destroying their carriers (Sahin, 2014; Top et al., 2020).

\section{Intellectual Stimulation}

The leaders who make their followers be more rational instead of being emotional making type of educational environment. The hard work, great result and innovation is all sources from that healthy mind and encourage by it (Budur, 2018b). In learning and teaching which are the main in education process the great teacher always promote follower's commitment and success (Yildiz and Budur, 2019). For example, most of the time the great teachers and instructors claim and believe that when they teach their students, they learn and get knowledge more than their students most of the time. As a result, the great leader should be a great teacher in same time (Mohammed and Shahin, 2020).

\section{Individualized Consideration}

The relationship between the leader and followers is important that these relations change from a person to another. There are employees that have a close and good relationship with their leader, this helps both to be more productive and providing as much as they can for the organization because they feel valued and that is what makes them committee and what makes them trust the organization in the high range. The best way for transformation leaders is working by one on one. So, the leader should know which structure is needed for which project to avoid confusion and mistakes inside the organization. Regarding the problems and 
obstacles that the organization faces, the leader should be responsible to find out the easiest way to solve them (Dinc, 2017).

\section{Employee Commitment}

Employment commitment is the degree of interest that an employee has for his/her tasks assigned to a workplace. Obligation senses that an individual has towards the aims, purpose, and vision of the organization with which he or she is identified. In an organization, high levels of employees' satisfaction are connected to work commitment and interest in their organization (Lee et al., 2020). This results in superior company efficiency, which in turn leads to improved profitability, productivity, retention of employees, and an overall improvement in the work climate (Zaim et al., 2020). Further, based on the current literature, employee commitment has been investigated under three main characteristics, which are normative commitment, continues commitment, and affective commitment (Altun, 2017; Celik and Yildiz, 2017).

Normative Commitment: First, the employee's normative commitment or "sense of obligation to stay "In an organization, high levels of employee satisfaction are connected to work commitment and interest in their organization. This obligation which maybe expectation, believes, fear or just idea or thinking that, what he/she doing is the rights and he/she got to be committed to it and be obligate as much as possible and provide what he/she can (Kamal and Shawkat, 2020).

Continues Commitment: The second type is employee continuous commitment also called "fear of loss commitment". This type of commitment occurs when employee weigh up the pros and cons of leaving the company. Since the experience by leaving the job might be greater than the profit than employee think. However, they feel needs to remain in the current company (Amin \& Ahmed, 2020). This is the result of the fear and unconfident the employee might feel. The employee might feel that if he/she goes to another place, they will not feel happy and satisfied. Also, they might have the fear of trying new experience and things. The employee feels that he/she might face obstacles and problems that he/she will not be able to solve easily. In this case, the employee stays at his/her job, not because they are satisfied or happy with the job but because they do not have other choices (Ali et al., 2020; Shawkat et al., 2020).

Affective Commitment: The last type refers to the employee affective commitment. This form of dedication happens when employee feel a sense of duty to their business (Sardar \& Mahdi, 2021). It's related with the organization in hard time also that is the result of powerful believes in the organization goals, mission, and vision (Ali et al., 2020; Ali, 2021).

\section{Family Business}

The family business can be defined as the organization which runs by the family members. Within the broadest sense, family commerce is a venture where family individuals have an impact over the decisions and strategies of the company. Other criteria for a family trade include that the manager of the company, or the relatives still run the company on a day-byday premise, and where numerous eras take part in day-by-day operations and have critical administration duties (Holland and Bolton 1984). 
Accordingly, in the Kurdistan region of Iraq there are many family businesses such as, Qaiwan group which is managed and run by the family members and they named Qaiwan according to their village. The Qaiwan group was at first just a construction company and after that enter the oil industry. However, nowadays they are almost in every sector and industry in the region. From the electric, supermarket food, medicine and so on... Another example is Faruq company or Faruq holding which own and run by Faruq family. They initially started with Asia cell which is telecommunication company and providing cellphone services and internet service in the whole of Iraq. Then soon after they have also started new businesses such as, Faruq medical city which huge hospital also under Faruq holding company and it has Asia insurance which provides insurance offers. Furthermore, Anudeep company which is the concreate company and it run by the family members also that they have a liquid and fresh concrete and having the trucks which get it to the building and their activity in Sulaimany city. The number of the examples could be increased but for the aim of study that we focus on the connection between transformational leadership and employee affective commitment these examples provide enough evidence to represent the structure of the family businesses in the region.

\section{Hypotheses of the Study}

Based on the aim of the study following hypotheses have been proposed to test in the following sections.

H1 TL has significant impact on AC.

H2 Being a family member of the company has significant impact on their AC.

\section{Methodology}

- Participants and Procedures

The study consists of 21 questions, which has been applied through questionnaire. We have collected date through interviews as visiting various family businesses in Sulaymaniyah city of Kurdistan. In total, 7 companies from health sector, information technology, hospitality, financial, communication, and energy sectors. Accordingly, more than 400 questionnaires have been separated and 345 have been accepted for further analyses of the study.

There were 3 sections in the questionnaire, which were demographic questions, transformational leadership questions that contains 8 questions and adopted from Budur (2020) and Obeidat and Zyod (2015) and lastly affective commitment questions that adopted from Burton and Peachey (2014). Further, participants answered questions through Likert scale, from 1 to 5 which 1 represent strongly disagree and 5 represent strongly agree, and the other options were 2 disagree, 3 natural and 4 agree with which were in between 
- Demographics of the Study

\begin{tabular}{ll}
\hline Gender & $\%$ \\
\hline Male & 95 \\
Female & 5 \\
\hline Age & $\%$ \\
\hline $18-25$ & 12 \\
$26-35$ & 51 \\
$36-45$ & 31 \\
$46-55$ & 4 \\
$56+$ & 2 \\
\hline Position & $\%$ \\
\hline Top Manager & 2 \\
Manager & 5 \\
Supervisor & 11 \\
Normal Staff & 82 \\
\hline Education & $\%$ \\
\hline High School & 60 \\
University & 28 \\
Master or PhD & 12 \\
\hline Experience & $\%$ \\
\hline Less than 1 year & 38 \\
1-5 years & 32 \\
6-10 years & 18 \\
11-15 years & 7 \\
16+ years & 5 \\
\hline Family member of the company & 70 \\
\hline Yes & 30 \\
No & \\
\hline
\end{tabular}

Based on the demographics of the study, majority of the participants are male (95\%) and $70 \%$ of all participants is the family member of the company owners. Besides, the again majority of the respondents is between $26-45$ (82\%) years old. As experience, $38 \%$ has less than one year and $32 \%$ has experience between $1-5$ years. Finally, $82 \%$ of the participants are normal employees who do not have any managerial role in the organization.

\section{Validity}

The reliability of the dimensions has been calculated through SPSS software. In this respect, transformational leadership has the reliability 0.871 with 8 items and affective commitment has 0.81 with 4 items. 1 item has been excluded from analysis due to lower level result. As a result, dimensions provide enough reliability for further analyses.

\begin{tabular}{lll}
\hline Reliability Statistics & & \\
\hline & Cronbach's Alpha & N of Items \\
Affective Commitment & 0.81 & 4 \\
Transformational Leadership & 0.871 & 8 \\
\hline
\end{tabular}




\section{Analyses}

\section{Regression Analysis}

Regression analysis helps to evaluate the relationship between independent and dependent variables. Besides, $R$ square is the variant that defines this link between variables. According to our evaluation through SPSS analysis, it has been observed that transformational leadership (TL) had significant positive impact on affective commitment (AC). On the other hand, we have found that being family member in the company had significant negative impact on their affective commitment.

\begin{tabular}{|c|c|c|c|c|c|c|}
\hline Independent & $\begin{array}{l}\text { Dependen } \\
t\end{array}$ & $\begin{array}{l}\text { Adjusted } \\
\text { Square }\end{array}$ & $\mathbf{R}$ & $\begin{array}{l}\text { Coefficients } \\
\text { value }\end{array}$ & T stat & Result \\
\hline TL & $A C$ & 0.377 & & 0.597 & $\begin{array}{l}14.29 \\
8\end{array}$ & $\begin{array}{l}\text { Accepte } \\
\text { d }\end{array}$ \\
\hline $\begin{array}{l}\text { Family } \\
\text { Member }\end{array}$ & $A C$ & 0.377 & & -0.122 & -2.925 & $\begin{array}{l}\text { Accepte } \\
\text { d }\end{array}$ \\
\hline
\end{tabular}

\section{Conclusion}

The study initially aimed to investigate the effect of transformational leadership on affective commitment in the family businesses in the Kurdistan region of Iraq. Secondly, it has been proposed to test the effectiveness of being family membership in the proposed organization in the region. In this respect, transformational leadership positively leveraged employee affective commitment, while family membership significantly decreased their affective commitment.

\section{Contribution of the Study}

The study has several implications. Initially, it was observed that transformational leadership has impact on the affective commitment. Therefore, it is suggested to the managers to practice the dimensions of the transformational leadership such as motivation, consideration, stimulation, and influence so that their employees will be more attached with the organization. To the theoretical implications of the study, it can be suggested that in Kurdish culture, transformational leadership has significant place by means of affective commitment to the organization.

Besides, the study suggest that family membership negatively affected with the affective commitment to the organization. The implication to this finding can be explained as that; when the family members are in the same organization, they are not happy to work together and in return, they don't feel good in the organization. This might be reducing their affective commitment to the organization. Secondly, because of jealous behaviors, they might not be happy to be together. As result, the study suggests managers to reduce the number of family members in the organizations and create more professional atmosphere. Theoretically it can be suggested that in Kurdish culture employees don't feel committed to the organization affectively in case it is a family business.

In these regards, the further studies should evaluate other type of leadership styles in the same topic. Further, the studies should evaluate the type of family members who are committed or not to the organization especially in the small and medium enterprises. 


\section{References}

Ali, M. O., Tawfeq, A. O., \& Dler, S. M. (2020). Relationship between Diversity Management and Human Resource Management: Their Effects on Employee Innovation in the Organizations. Black Sea Journal of Management and Marketing, 1(2), 36-44.

Ali, S. H. (2018). How effective Kurdistan regional government size in terms of economic growth compared to Qatar. Journal of Raparin University-Vol, 5(15), 87.

Ali, S. H. (2021). The Moderating Effect of Ethical Leadership between Psychological Ownership of Knowledge and Knowledge Hiding: An Empirical Study on the Public Universities in Northern Iraq. Revista Argentina de Clínica Psicológica, 30(2), 178.

Ali, S. H., \& Sagsan, M. (2020, December). The Mediating role of Knowledge-Oriented Leadership Between Bureaucratic Culture and Knowledge Creation: The case of Public Universities in Northern Iraq. In European Conference on Knowledge Management (pp. 37-XIV). Academic Conferences International Limited.

Ali, S. H., \& Yildiz, Y. (2020). Leadership effects on CSR employee, media, customer, and NGOs. Manag Econ Res J, 6(1), 12354.

Altun, M. (2017). The effects of teacher commitment on student achievement: A case study in Iraq. International Journal of Academic Research in Business and Social Sciences, 7(11), 417-426.

Altun, M. (2017). The effects of teacher commitment on student achievement. International Journal of Social Sciences \& Educational Studies, 3(3), 51.

Amin, N. G. A., \& Ahmed, R. J. H. (2020). Perception of Women-Only Cafés in Kurdistan Region of Iraq. Black Sea Journal of Management and Marketing, 1(1), 29-40.

Appelbaum, S. H., Mitraud, A., Gailleur, J., lacovella, M., Gerbasi, R., \& Ivanova, V. (2008). The impact of organizational change, structure, and leadership on employee turnover: a case study. Journal of Business Case Studies, 4(1), 21-38

Bass, B. M. (1999). Two decades of research and development in transformational leadership. European journal of work and organizational psychology, 8(1), 9-32.

Budur, T. (2018b). Analytic Hierarchy Process to Evaluate Corporate Image, Trust, and Switching Cost of GSM Operators: A Case of Kurdistan Region of Iraq. International Journal of Social Sciences \& Educational Studies, 5(2), 241-250

Budur, T. (2018a). The impact of Al-Ghazali's virtues on organizational commitment and performance: A case Study at private education institutions in Kurdistan Region of Iraq. Icabep, Erbil-Iraq, 2, p21.

Budur, T. (2020). Impact of Transformational Leadership on Customer Satisfaction: Mediating effects of Employee Performance and Organizational Citizenship Behaviors. (Unpublished doctoral dissertation). International Burch University.

Budur, T., \& Demir, A. (2019a). Leadership effects on employee perception about CSR in Kurdistan Region of Iraq. International Journal of Social Sciences \& Educational Studies, 5(4), 184-192.

Budur, T., \& Demir, A. (2019b). Leadership perceptions based on gender, experience, and education. International Journal of Social Sciences \& Educational Studies, 6(1), 142-154.

Budur, T., \& Poturak, M. (2021a). Transformational leadership and its impact on customer satisfaction. Measuring mediating effects of organisational citizenship behaviours. Middle East Journal of Management, 8(1), 67-91.

Budur, T., \& Poturak, M. (2021b). Employee Performance and Customer Loyalty: Mediation effect of Customer Satisfaction. Middle East Journal of Management.

Burns, J. M. (1978). Leadership. New York: Harper \& Row. 
Burton, L. J., \& Peachey, J. W. (2014). Organizational culture mediates the relationship between transformational leadership and work outcomes. Journal of Intercollegiate Sport, 7(2), 153-174.

Celik, B., \& Yildiz, Y. (2017). Commitment to the teaching profession. International Journal of Social Sciences \& Educational Studies, 4(2), 93-97.

Conger, J. A., \& Kanungo, R. N. (1994). Charismatic leadership in organizations: Perceived behavioral attributes and their measurement. Journal of organizational behavior, 15(5), 439-452.

Demir, A., \& Budur, T. (2019). Roles of leadership styles in corporate social responsibility to non-governmental organizations (NGOs). International Journal of Social Sciences \& Educational Studies, 5(4), 174-183.

Demir, A., Budur, T., \& Heshmati, A. (2020). Antecedents of trust, corporate image, and switching costs: a case in telecommunication services in the Kurdistan region of Iraq. International Journal of Mobile Communications, 19(1), 53-74.

Demir, A., Budur, T., Omer, H. M., \& Heshmati, A. (2021). Links between knowledge management and organisational sustainability: does the ISO 9001 certification have an effect? Knowledge Management Research \& Practice, 1-14.

Dinc, M. S. (2017). Organizational commitment components and job performance: Mediating role of job satisfaction. Pakistan Journal of Commerce and Social Sciences (PJCSS), 11(3), 773-789.

Durmaz, O. (2017). Investigation of the motivation parameters in health care establishments. International Journal of Social Sciences \& Educational Studies, 3(4), 4453.

Faeq, M. (2020). Performance Evaluation Criteria Development Process for Academic Staff at Universities. Black Sea Journal of Management and Marketing, 1(1), 59-70.

Hamid, D., \& Durmaz, O. (2021). Organizational Culture Impact on Employee Innovative Behaviors in Kurdistan. Black Sea Journal of Management and Marketing, 2(1), 63-72.

Kamal, T., \& Shawkat, S. (2020). The Impact of Dynamic Capabilities on Knowledge Management in Kurdistan Region of Iraq. Black Sea Journal of Management and Marketing, 1(1), 41-48.

Lee, A. N., Nie, Y., \& Bai, B. (2020). Perceived principal's learning support and its relationships with psychological needs satisfaction, organizational commitment and change-oriented work behavior: A Self-Determination Theory's perspective. Teaching and Teacher Education, 93, 103076.

Meyer, J. P., Allen, N. J., \& Gellatly, I. R. (1990). Affective and continuance commitment to the organization: Evaluation of measures and analysis of concurrent and time-lagged relations. Journal of applied psychology, 75(6), 710.

Mohammed, S. S., \& Shahin, O. (2020). Service Quality Perspectives in Telecommunication Sector: Trust and Loyalty Investigation. Amazonia Investiga, 9(28), 394-403.

Mohammed, S. S., Suleyman, C., \& Taylan, B. (2020). Burnout Determinants and Consequences Among University Lecturers. Amazonia Investiga, 9(27), 13-24.

Obeidat, B. Y., \& Zyod, D. S. (2015). The associations among transformational leadership, transactional leadership, knowledge sharing, job performance, and firm performance: A theoretical model. Journal of Social Sciences (COES\&RJ-JSS), 4(2), 848-866.

Poturak, M., Mekic, E., Hadžiahmetovic, N., \& Budur, T. (2020). Effectiveness of Transformational Leadership among Different Cultures. International Journal of Social Sciences \& Educational Studies, 7(3), 119-129. 
Rashid, C. A., Salih, H. A., \& Budur, T. (2020). The role of online teaching tools on the perception of the students during the lockdown of Covid-19. International Journal of Social Sciences \& Educational Studies, 7(3), 178.

Sahin, O. (2014). An investigation of student satisfaction factors. Journal of Research in Business and Management, 2(6), 8-1.

Sardar, M., \& Mahdi, T. (2021). Impact of Organizational Culture on Innovative Work Behavior. Black Sea Journal of Management and Marketing, 1(2), 11-20. https://doi.org/10.47299/bsjmm.v1i2.57

Serin, H. (2018). The use of extrinsic and intrinsic motivations to enhance student achievement in educational settings. International Journal of Social Sciences \& Educational Studies, 5(1), 191-194.

Shawkat, S., Aydinli, C., \& Demir, S. (2020). Elaborating Determinants of Location Strategy: A Case Study in Sulaymaniyah, Kurdistan Region of Iraq. Black Sea Journal of Management and Marketing, 1(2), 21-35.

Tajeddini, K. (2015) Using the Integration of Disparate Antecedents to Drive World-Class Innovation Performance: An Empirical Investigation of Swiss Watch Manufacturing Firms, Tékhne, Review of Applied Management Studies, Vol. 13, No. 1, pp. 34-50

Top, C., Abdullah, B. M. S., \& Faraj, A. H. M. (2020). Transformational Leadership Impact on Employees Performance. Eurasian Journal of Management \& Social Sciences. 1(1), 49-59

Torlak, N. G., Demir, A., \& Budur, T. (2019). Impact of operations management strategies on customer satisfaction and behavioral intentions at café-restaurants. International Journal of Productivity and Performance Management. Vol. 69 No. 9, pp. 1903-1924.

Torlak, N. G., Demir, A., \& Budur, T. (2021). Decision-making, leadership and performance links in private education institutes. Rajagiri Management Journal. Doi:10.1108/RAMJ10-2020-0061.

Ulrich, D., Kryscynski, D., Ulrich, M., \& Brockbank, W. (2017). Leaders as paradox navigators. Leader to Leader, 2017(86), 53-59.

Yildiz, Y., \& Budur, T. (2019). Introducing Environmental Awareness to College Students with Curricular and Extracurricular Activities. International journal of Academic Research in business and Social Sciences, 9(3)667-675.

Zaim, H., Demir, A., \& Budur, T. (2020). Ethical leadership, effectiveness and team performance: An Islamic perspective. Middle East Journal of Management, 8(1), 42-66.

Zardasht, P., Omed, S., \& Taha, S. (2020). Importance of HRM Policies on Employee Job Satisfaction. Black Sea Journal of Management and Marketing, 1(1), 49-57. 